\title{
Adult Brain Ependymoma
}

National Cancer Institute

\section{Source}

National Cancer Institute. Adult Brain Ependymoma. NCI Thesaurus. Code C9372.

An ependymoma of the brain occurring in adults. 